\title{
First record of Aporodoris millegrana (Alder et Hancock, 1854) (Gastropoda Heterobranchia Nudibranchia) in the lonian Sea, central Mediterranean Sea
}

\author{
Andrea Lombardo* \& Giuliana Marletta \\ Department of Biological, Geological and Environmental Sciences - Section of Animal Biology, University of \\ Catania, via Androne 81, 95124 Catania, Italy \\ *Corresponding author: andylombardo94@gmail.com
}

\begin{abstract}
The first record of Aporodoris millegrana (Alder et Hancock, 1854) (Gastropoda Heterobranchia Nudibranchia) in the Ionian Sea (central Mediterranean Sea) is here presented. This species was originally described for the British Isles and then, under different synonyms, was reported for the Atlantic coasts of France, Canary Islands, Madeira and the Strait of Gibraltar. In the Mediterranean Sea, this species has been only reported for different localities along the Catalan coast. This record is based on the finding of a A. millegrana specimen in a station along the central-eastern coast of Sicily (Italy). The individual was found under a stone at a depth of 6.4 $\mathrm{m}$ on a rocky seabed. In the last years, some Atlantic Nudiplera, which were never reported before, have been increasingly found in the Ionian Sea. In view of the rising water temperature in the Mediterranean Sea, the Atlantic termophilic species could settle in new areas of the Mediterranean. Nevertheless, it is not excluded that maybe $A$. millegrana, since is rare and with a sciaphilous behaviour, could be underestimated until now in the Mediterranean Sea.
\end{abstract}

KEY WORDS Aporodoris millegrana; Mediterranean Sea; Sicily; Taringa fanabensis; Taringa tarifaensis.

Received 12.07.2020; accepted 15.10.2020; published online 22.11.2020

\section{INTRODUCTION}

Aporodoris millegrana (Alder et Hancock, 1854 ) is a nudibranch belonging to the family Discodorididae Bergh, 1891. Overall, this species had a troubled taxonomic history. Indeed, previously, this species was included in different genera: Doris Linnaeus, 1758, Archidoris Bergh, 1878, Discodoris Bergh, 1877, Taringa Er. Marcus, 1955 and Thordisa Bergh, 1877 (Dayrat, 2010; Ballesteros et al., 2016). Moreover, two species, Taringa fanabensis Ortea et Martínez, 1992 and T. tarifaensis García-Gómez et al., 1993, described for Canary Islands and Cadiz, respectively, are nowadays con- sidered as synonyms of A. millegrana (Valdés \& Gosliner, 2001). Nevertheless, according to Dayrat (2010) these synonyms could be possible but further studies would be needed to confirm this hypothesis. Indeed, more information are necessary to understand the infra-specific and inter-specific variations of morphological features of the species of the genera Aporodoris Ihering, 1886 and Taringa, in the Atlantic Ocean and the Mediterranean Sea (Dayrat, 2010).

Aporodoris millegrana was originally described by Alder \& Hancock (1854) for Torbay (British Isles) as "Doris millegrana". Then, this species was found along the French coasts near Wimereux 
(Bouchet \& Tardy, 1976). Subsequently, it was reported for Tenerife (Canary Islands) by Ortea \& Martinez (1992), as "Taringa fanabensis", and for Tarifa (Cadiz, Strait of Gibraltar), by García-Gomez et al. (1993), as "Taringa tarifaensis". In 1999, this species was found in Madeira and was reported as "Taringa cf. fanabensis" (Wirtz, 1999). In 2001, it was found in Canary Islands by Ortea et al. (2001) (as "Taringa fanabensis") and in Madeira by Malaquias et al. (2001) (as "Taringa cf. fanabensis"). Then, Moro et al. (2003) reported this species another time for Canary Island as "Taringa fanabensis". Finally, Ballesteros et al. (2016) observed this species in different localities (Cadaqués, Begur and l'Ametlla de Mar) of the Catalan coast. Consequently, A. millegrana in the Mediterranean Sea, was reported only along the Spanish coasts. The present report, thus, represents the first record of $A$. millegrana in Ionian Sea (central Mediterranean Sea).

\section{MATERIAL AND METHODS}

The present study was carried out in a station called Santa Maria La Scala $(37,6125$ N; 15,175389 E), located along the central-eastern coast of Sicily (Italy). This fishing town is sited in the municipality of Acireale and hosts a small harbour. Santa Maria La Scala is situated along Etna eastern slopes (Sciuto et al., 2017) and presents a coastal scarp extended for $6 \mathrm{~km}$, denominated "Timpa". In this station there are an Oriented Natural Reserve called "La Timpa" and a Site of Community Importance (SCI), named "Timpa of Acireale" (Catra et al., 2006). Due to the high permeability of Etna's vulcanites and to the flow of freshwaters from Etna to the sea, there are several springs (Catra et al., 2006). Moreover, the seabed, where the specimen was found, has a sloping topography and is characterized by basaltic outcrops. Aporodoris millegrana specimen was identified in vivo and photographed through an Olympus TG-4 Underwater Camera, during a scuba diving, between 9-11:30 a.m., conducted by the authors.

\section{RESULTS}

On $19^{\text {th }}$ May 2020, an A. millegrana specimen
(Figs. 1-4) was found under a stone with sponges and bryozoans, at a depth of $6.4 \mathrm{~m}$. The specimen was about $20 \mathrm{~mm}$ long, with a flattened appearance. The individual had a violet-brownish body, with a dense pattern of tubercles on the notum. Along the edge of notum there were small bright white spots. Moreover, the notum was characterized by scattered white lines and darker patches. On each side of the visceral mass there was a small group of more evident white-yellowish tubercles. Rhinophores, yellowish with brown stripes, presented lamellae and were mucronate at the tip. The gills had the same colouring of the rhinophores. The edge of rhinophore and gill sheaths had white spiculous tubercles.

\section{DISCUSSION}

The specimen of $A$. millegrana (Figs. 1-4) reported in this study was similar to that described by Moro \& Ortea (2012). Indeed, they observed that the body colour of this species is brown-violet with distinctive tubercles regularly arranged on the notum. In lateral view the body has a flattened shape. Rhinophores have greyish peduncles with 14 brownish lamellae and are mucronate at the tip. The rhinophore sheaths have tubercles, which are similar of those on the notum. The gills have 6 tripennate leaves with greyish lamellae. The rachis of the leaves is dark at the base of its external face and white inside. In the specimen found in this study, we observed about 8-10 lamellae on each rhinophore, but it was not possible to define the number of gill leaves. Moreover, the specimen reported by us had very similar external morphological features to those of the specimens figured in Wirtz (1999, Plate 4, fig. 6) and in Trainito \& Doneddu (2014: 70). Therefore, on the basis of specimens reported in the mentioned literature, we believe that the specimen found by us was $\mathrm{A}$. millegrana.

Just like to Dayrat (2010), Trainito \& Doneddu (2014) and Ballesteros et al. (2016), we believe that within the genus Taringa (which previously included $A$. millegrana) there are a lot of morphological similarities among species, thus further anatomical and molecular studies are necessary to clarify species delimitation inside this group. 

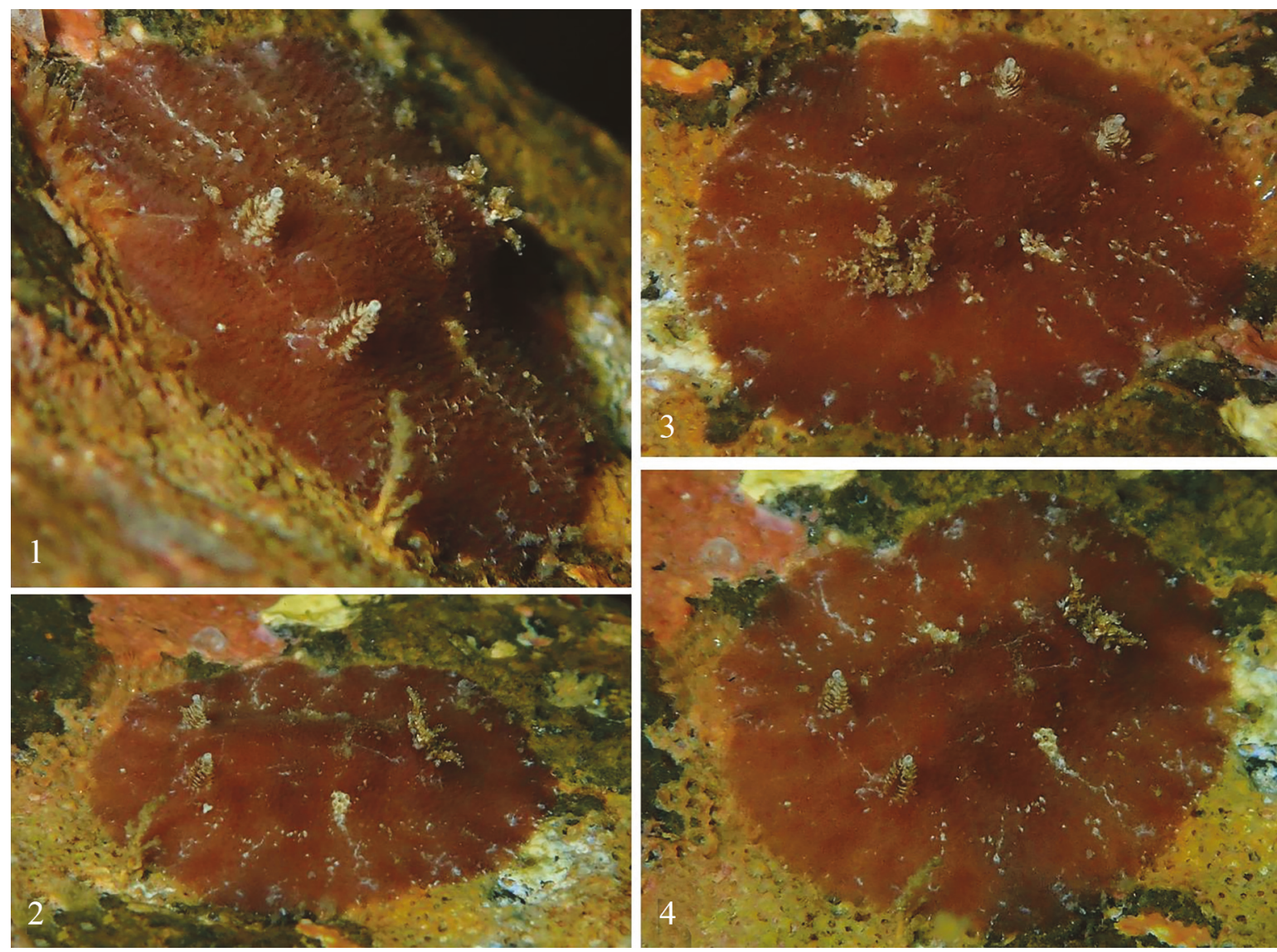

Figures 1-4: Aporodoris millegrana specimen found in Santa Maria La Scala (Sicily). Fig. 1) Anterior view showing the pattern of tubercles on the notum. Fig. 2) Right lateral view of the individual. Fig. 3) Posterior view of the specimen. Fig. 4) Dorsal view of the specimen (photos A. Lombardo).

\section{CONCLUSIONS}

In this study, the presence of $A$. millegrana in the Ionian Sea and in the central Mediterranean Sea was reported for the first time. Indeed, this species has been previously reported only in the Atlantic Ocean and in the western Mediterranean Sea. In the last years, some Atlantic Nudiplera, which were never reported before, have been increasingly found in the Ionian Sea. For example, Pleurobranchus wirtzi Ortea, Moro \& Caballer, 2014, distributed in Canary Island, Madeira and Azores, and Taringa tritorquis Ortea, Perez \& Llera, 1982, distributed in Canary Islands and presumably Madeira, have been recently reported for the first time in the Mediterranean Sea (Lombardo \& Marletta, 2019; Gerovasileiou et al., 2020; Lombardo \& Marletta, 2020). It has been observed that many Atlantic marine species introduced in the Mediterranean Sea, succeed in spreading east- wards within the Basin. Therefore, it has been hypothesized that the dispersal of Atlantic species and their propagules is driven by the hydrodynamic regime related to the Atlantic current in the western Mediterranean Sea. Moreover, the colonization success of Atlantic species into the Mediterranean Sea is related to the climate match between their native and their colonized environment. Indeed, a species expanding into an area within the same latitudinal range can experience similar environmental conditions (e.g., temperature) and successfully establish in the new area Lasram et al., 2009). In view of the rising water temperature in the Mediterranean Sea, the Atlantic termophilic species, like A. millegrana, $P$. witzi and T. tritorquis, could settle in new areas of the Mediterranean Sea. Nevertheless, it is not excluded that maybe these species, since are rare and with a sciaphilous behaviour, could be underestimated until now in the Mediterranean Sea. 


\section{REFERENCES}

Alder J. \& Hancock A., 1854. Notice of some new species of British Nudibranchiata. Annals and Magazine of Natural History, ser. 2, 14: 102-105.

Ballesteros M., Madrenas E. \& Pontes M., 2016. Actualización del catálogo de los moluscos opistobranquios (Gastropoda: Heterobranchia) de las costas catalanas. Spira, 6: 1-28.

Bouchet P. \& Tardy J., 1976. Faunistique et biogégraphie des nudibranches des côtes françaises de l'Atlantique et de la Manche. Annales de l'institut océanographique, 52: 205-213.

Catra M., Giaccone T., Giardina S. \& Nicastro A., 2006. Il patrimonio naturale marino bentonico della Timpa di Acireale (Catania). Bollettino dell'Accademia Gioenia di Scienze Naturali, 39 (366): 129-158.

Dayrat B., 2010. A monographic revision of basal Discodorid sea slugs (Mollusca: Gastropoda: Nudibranchia: Doridina). Proceedings of the California Academy of Sciences, 61: 1-403.

García-Gómez J. C., Cervera J. L. \& García-Martin S. F., 1993. A new species of dorid nudibranch of the genus Taringa Marcus, 1955 (Mollusca: Opisthobranchia) from the southern Iberian Peninsula, with remarks on world species of the genus. Journal of Natural History, 27: 565-574.

Gerovasileiou V., Akyol O., Al-Hosne Z., Alshikh Rasheed R., Ataç E., Bello G., Ćetković I., CorsiniFoka M., Crocetta F., Denitto F., Guidetti P., Gül B., Insacco G., Jimenez C., Licchelli C., Lipej L., Lombardo A., Mancini E., Marletta G., Michailidis N., Pešić A., Poursanidis D., Refes W., Sahraoui H., Thasitis I., Tiralongo F., Tosunoğlu Z., Trkov D., Vazzana A. \& Zava B., 2020. New records of rare species in the Mediterranean Sea (May 2020). Mediterranean Marine Science, 0: 340-359. https:// doi.org/10.12681/mms. 22148

Lasram F. B. R., Tomasini J. A., Romdhane M. H., Chi T. D. \& Mouillot D., 2009. Historical colonization of the Mediterranean Sea by Atlantic fishes: do biological traits matter? Hydrobiologia, 607: 51-62. https://doi.org/10.1007/s10750-008-9366-4

Lombardo A. \& Marletta G., 2019. A new Atlantic immigrant in the Mediterranean Sea: Pleurobranchus wirtzi Ortea, Moro et Caballer, 2014 (Gastropoda Pleurobranchida). Biodiversity Journal, 10: 275-278. https://doi.org/10.31396/Biodiv.Jour.2019.10.3.275. 278
Lombardo A. \& Marletta G., 2020. New records of Biuve fulvipunctata (Baba, 1938) (Gastropoda Cephalaspidea) and Taringa tritorquis (Ortea, Perez \& Llera, 1982) (Gastropoda Nudibranchia). Biodiversity Journal, 11(2): 587-591. https://doi.org/10.31396/Biodiv.Jour.2020.11.2.587.591

Malaquias M. A. E., Cervera J. L., Abreu A. D. \& LópezGonzález P. J., 2001. The Opisthobranch Molluscs from Porto Santo Island (Madeira Archipelago, Northeastern Atlantic Ocean). Iberus, 19: 75-82.

Moro L., Ortea J., Bacallado J. J, Caballer M. \& Acevedo I., 2003. Anaspidea, Cephalaspidea, Gymnosomata, Notaspidea, Nudibranchia, Sacoglossa y Thecosomata. In: Moro L., Martín J. L., Garrido M. J. \& Izquierdo I. (Eds.), 2003. Lista de especiesmarinas de Canarias (algas, hongos, plantas y animales). Consejería de Política Territorial y Medio Ambiente del Gobierno de Canarias, Santa Cruz de Tenerife, Spain, 93-98.

Moro L. \& Ortea J., 2012. Notas en Opistobranchia (Mollusca, Gastropoda) 3. Sobre la propuesta de sinonimia de Taringa fanabensis Ortea \& Martínez, 1982 con Aporodoris millegrana Alder \& Hancock, 1854 (Mollusca: Nudibranchia: Discodorididae). Vieraea, 40: 83-92.

Ortea J. \& Martínez E., 1992. Description de una nueva especie del genero Taringa en las Islas Canarias. Revista de la Academia Canaria de Ciencias, 4: 95-101.

Ortea J., Moro L., Bacallado J.J. \& Herrera R., 2001[2000]. Catálogo actualizado de los Moluscos Opistobranquios de las Islas Canarias. - Revista de la Academia Canaria de Ciencias, 12: 105-136.

Sciuto F., Rosso A., Sanfilippo R., Alongi G., Catra M., Serio D., Bejaoui S., Leonardi R. \& Viola A., 2017. First data on ostracods and foraminifera living in Cystoseira associations in western Ionian Sea. Mediterranean Marine Science, 18/3: 393-405. https:// doi.org/10.12681/mms.2085

Trainito E. \& Doneddu M., 2014. Nudibranchi del Mediterraneo. Il Castello, Cornaredo, 192 pp.

Valdés Á. \& Gosliner M., 2001. Systematics and phylogeny of the caryophyllidia - bearing dorids (Mollusca, Nudibranchia), with descriptions of a new genus and four new species from Indo - Pacific deep waters. Zoological Journal of the Linnean Society, 133: 103-198. https://doi.org/10.1111/j.1096-3642. 2001.tb00689.x

Wirtz P., 1999. Opisthobranch Molluscs from the Madeira Archipelago. Vita Marina, 46: 1-18. 